\title{
A retrospective review of general paediatric inpatient deaths over time
}

\author{
Amanda Roth ${ }^{1 *}$, Jeremy Friedman², Adam Rapoport ${ }^{2}$, Kim Widger ${ }^{2}$ \\ From 4th International Conference for Healthcare and Medical Students (ICHAMS) 2014 \\ Dublin, Ireland. 24-25 October 2014
}

\section{Background}

To retrospectively review changes in the circumstances of general paediatric inpatient deaths at a tertiary hospital over three different time periods.

\section{Methods}

Data was retrospectively collected for all patients who died on the General Paediatric Ward (the Ward) or in the Paediatric Intensive Care Unit (PICU) at this tertiary hospital, in the years 1998, 2005, and 2012. Patients who died in the PICU were considered to have a "general paediatric diagnosis" if their underlying condition or acute diagnosis would have normally resulted in admission to a General Paediatric Ward. The data elements collected were related to: demographic information about the child, health services data, information about provision and orders related to CPR at time of death and the involvement of palliative care services.

\section{Results}

85 inpatients met the inclusion criteria; 35 in 1998, 27 in 2005, and 23 in 2012. Differences in location of death were noted across the three time periods. 94.3\% of general paediatric patients died in the Paediatric Intensive Care Unit (PICU) in 1998; 59\% died in the PICU in 2005, and $69.6 \%$ died in the PICU in 2012. The chronological age at which these children died decreased over the three time periods, varying from a median age of death of 5.96 years in 1998, to 4.58 years in 2012. The proportion of patients with 'no Cardiopulmonary Resuscitation' (no CPR) orders at the time of death increased over the 14 year period from $31 \%$ in 1998 to $87 \%$ in 2012 . Similarly, the proportion of patients with palliative care involvement increased from $8.6 \%$ in 1998 to $73.9 \%$ in 2012.

\section{Conclusions}

The number of inpatient general paediatric deaths at this tertiary hospital has decreased from 1998 to 2012. A larger proportion of these deaths are occurring on the Wards rather than in the PICU over time. 'No CPR' orders and palliative care consultations are becoming more prevalent in these patients prior to death.

\section{Authors' details}

${ }^{1}$ Royal College of Surgeons in Ireland, Dublin, Ireland. ${ }^{2}$ The Hospital for Sick Children, Toronto, Canada.

Published: 27 October 2015

\section{References}

1. Burns K, Casey P, Lyle R, MacBird T, Fussell J, Robbins J: Increasing Prevalence of Medically Complex Children in US Hospitals. Pediatrics 2010, 126: 638-646.

2. Simon T, Berry J, Feudtner C, Stone B, Sheng X, Bratton S, Dean JM, Srivastava R: Children with Complex Chronic Conditions in Inpatient Hospital Settings in the United States. Pediatrics 2010, 126: 647-655.

3. Lindley LC, Lyon L, Lyon ME: A Profile of Children with Complex Chronic Conditions at End of Life among Medicaid Beneficiaries: Implications for Health Care Reform. J Palliat Med 2013, 16: 1-6.

4. Fraser L, Miller M, Draper E, McKinney P, Parslow R: Place of Death and Palliative Care Following Discharge from Paediatric Intensive Care Units. Arch Dis Child 2011, 96: 1195-1198.

5. Feudtner C, Christakis D, Zimmerman F, Muldoon John, Koepsell T: Characteristics of Death Occurring in Children's Hospitals: Implications for Supportive Care Services. Pediatrics 2002, 109: 887-893.

6. Ramanaryan P: Children Continue to Die in Intensive Care. Lancet Oncol 2007, 8: 455-560.

7. Feudtner C, Feinstein J, Satchell M, Zhao H, Kang T: Shifting Place of Death Among Children with Complex Chronic Conditions in the United States. 1989-2003. JAMA 2007, 297: 2725-2732.

8. Whitlock JA, Carter BS, Howenstein M, Gilmer MJ, Throop P, France D: Circumstances Surrounding the Deaths of Hospitalized Children: Opportunities for Pediatric Palliative Care. Pediatrics 2004, 114: 361-366.

9. Harris PA, Taylor R, Thielke R, et al: Research electronic data capture (REDCap) - A metadata-driven methodology and workflow process for providing translational research informatics support. Journal of Biomedical Informatics 2009, 42(2):377-81.

doi:10.1186/1753-6561-9-S7-A3

Cite this article as: Roth et al:: A retrospective review of general

paediatric inpatient deaths over time. BMC Proceedings 2015 9(Suppl 7):A3. 